\title{
PENGARUH MODEL BRAINSTORMING PADA PEMBELAJARAN SEJARAH TERHADAP KREATIVITAS SISWA DI KELAS X SMK SWASTA AL WASHLIYAH PASAR SENEN 2 MEDAN
}

Oleh:

Syarifah

Uci Ramadhani

\begin{abstract}
Abstrak
Jenis penelitian ini adalah quasi experiment (eksperimen semu) dengan tujuan untuk mengetahui ada tidaknya akibat dari suatu perlakuan yang ditujukan pada subjek yaitu siswa. Populasi dalam penelitian ini adalah seluruh siswa kelas X SMK Swasta Alwasliyah Pasar Senen 2 Medan yang terdiri dari 7 kelas dengan jumlah 223 siswa. Teknik sampling yang digunakan dalam penelitian ini adalah Random Sampling dengan mengambil 2 kelas dari 7 kelas secara acak yaitu kelas X TSM 1 sebagai kelas eksperimen dan kelas X TSM 2 sebagai kelas kontrol. Desain penelitian yang digunakan dalam penelitian ini adalah posttest only control design. Instrumen yang digunakan dalam penelitian ini adalah angket dengan model skala likert. Dari hasil penelitian terhadap kedua kelas yang diberi perlakuan yang berbeda yaitu kelas eksperimen diajarkan menggunakan model brainstorming dan kelas kontrol menggunakan model ceramah, ketika diterapkan model brainstorming di kelas eksperimen hampir seluruh siswa antusias dan ingin ikut berperan aktif dalam kegiatan diskusi kelompok, mereka berlomba mencari jawaban untuk menjawab dan memecahkan masalah yang diberikan. Ketika model ceramah diterapkan di kelas kontrol, tidak semua siswa aktif dalam pembelajaran, hanya beberapa siswa yang memang aktif saja yang berantusias dan semangat dalam belajar. Sedangkan sebagian siswa lain hanya mendengarkan dan tidak aktif saat belajar. Dari skor rata-rata hasil posstest juga terlihat bedanya, pada kelas eksperimen yaitu 74,06 dan pada kelas kontrol skor rata-rata nya 69,43. Hasil uji hipotesis menunjukkan nilai $t_{\text {hitung }}$ adalah 4,4179 dan $t_{\text {tabel }}$ 2,00172 dengan derajat kebebasan $\mathrm{df}=\mathrm{n}-\mathrm{k}$. Hasil perhitungan menunjukkan bahwa $\mathrm{t}_{\text {hitung }}(4,4179)>\mathrm{t}_{\text {tabel }}$ $(2,00172)$ yang berarti bahwa ada pengaruh model brainstorming pada pelajaran sejarah terhadap kreativitas siswa.
\end{abstract}

Kata kunci: Kreativitas siswa, model brainstorming 


\section{PENDAHULUAN}

Pelajaran sejarah adalah pelajaran yang mempelajari masa lalu. Dalam pergaulan sehari-hari pengertian sejarah mempunyai beberapa konotasi. Secara umum sejarah memang dikaitkan dengan peristiwa masa lampau, yaitu sejarah sebagai histoire realite dan sejarah sebagai kisah tentang masa lampau, histoirerecite. Namun juga ada yang mengaitkan dengan benda peninggalan dari masa lampau, misalnya patung atau candi. Hariyono (1995:51).

Pelajaran sejarah sering dianggap sebagai pelajaran hafalan dan membosankan. Pelajaran ini dianggap tidak lebih dari rangkaian angka tahun dan urutan peristiwa yang harus diingat. Hal ini sebenarnya juga disebabkan dari model mengajar guru yang kurang berinovasi dan kreatif. Pemerintah melalui Kementrian Pendidikan dan Kebudayaan melakukan perubahan kurikulum, dari kurikulum tingkat satuan pendidikan (KTSP) menjadi kurikulum 2013 yang berpusat pada peserta didik. Dalam kurikulum 2013 ini, guru mempunyai peranan penting dalam pelaksanaannya karena guru diharuskan untuk mengembangkan proses pembelajaran sesuai dengan kurikulum 2013 dan melaksanakan pembelajaran sesuai kompetensi-kompetensi pembelajaran.

Proses pembelajaran dalam kurikulum 2013 ini diharapkan adanya interaksi yang aktif antara guru dengan peserta didik. Namun, pada kenyataannya masih ada guru yang mengunakan model ceramah yang cenderung monoton. Berdasarkan hasil observasi peneliti di sekolah yang akan menjadi tempat penelitian, guru menggunakan model ceramah yang dianggap peserta didik tidak menarik. Pada saat menyampaikan pembelajaran guru memang menggunakan teknik tanya jawab, tetapi hanya ke beberapa siswa saja. Guru tidak memberikan pertanyaan secara umum untuk semua siswa melainkan hanya kepada siswa yang ditunjuk saja.

Hal ini membuat siswa yang lainnya merasa tidak diperdulikan karena tidak dilibatkan dalam pembelajaran. Guru menyampaikan materi tanpa melihat keadaan peserta didik dan mengharapkan semua peserta didik mendengarkan, mencatat, dan paham terhadap materi yang disampaikan. Penggunaan model ceramah yang seperti itu menimbulkan kejenuhan bagi peserta didik. Peserta didik menjadi bosan, mengantuk, dan cenderung pasif terhadap pembelajaran karena tidak diberi 
kesempatan untuk berbicara dan mengeluarkan pendapat, sementara guru justru asik sendiri menjelaskan pelajaran di depan kelas. Padahal, secara khusus sejarah punya banyak peluang untuk menawarkan bagaimana belajar untuk berpikir kreatif.

Guru sebaiknya memberikan pertanyaan atau sebuah masalah yang dapat diselesaikan bersama-sama. Hal ini dilakukan agar dapat merangsang kreativitas siswa dalam berpikir. Karena, kreativitas atau berpikir kreatif sebagai kemampuan untuk melihat bermacam-macam kemungkinan penyelesaian terhadap suatu masalah. Kreativitas merupakan suatu bentuk pikiran yang sampai saat ini masih kurang mendapat perhatian dalam pendidikan secara formal. Di sekolah, biasanya menekankan pengetahuan, ingatan, penalaran atau pengetahuan untuk berfikir logis yang hanya mempunyai jawaban paling tepat. Kebiasaan seperti inilah yang menghambat kreativitas seorang anak.

Kemampuan berpikir kreatif dapat dikembangkan melalui pendidikan. Pernyataan ini sesuai dengan rumusan dalam Undang-Undang nomor 20 Tahun 2003 tentang Sistem Pendidikan Nasional pasal 3 menyatakan bahwa:

"Pendidikan nasional berfungsi mengembangkan kemampuan dan membentuk watak serta peradaban bangsa yang bermartabat dalam rangka mencerdaskan kehidupan bangsa, bertujuan untuk berkembangnya potensi peserta didik agar menjadi manusia beriman dan bertaqwa kepada Tuhan Yang Maha Esa, berakhlak mulia, sehat, berilmu, cakap, kreatif, mandiri dan menjadi warga negara yang demokratis serta bertanggung jawab".

Pernyataan tersebut menunjukkan bahwa tujuan pendidikan bukan sekedar menciptakan lulusan yang memiliki predikat tamat belajar semata, tetapi lebih dari itu yaitu menciptakan lulusan yang berkualitas. Lulusan yang berkualitas ini diharapkan mampu memecahkan berbagai masalah baik bagi dirinya sendiri, maupun bagi lingkungan sekitarnya. Kemampuan yang demikian akan dimungkinkan jika lulusan pendidikan tersebut memiliki kreativitas.

Kreativitas siswa sangat bermakna dan perlu dipupuk dalam diri peserta didik sejak dini. Karena dengan berkreasi, orang dapat mewujudkan atau mengaktualisasikan dirinya dan perwujudan/aktualisasi diri merupakan kebutuhan pokok pada tingkat tertingi dalam hidup manusia. Maslow dalam Utami (2012:31). 
Menurut Hariyono (1995:10) kebebasan dalam beragumentasi dan berilustrasi dapat merangsang rasa ingin tahu (kuirositas) peserta didik. Kehausan untuk mencari dan menggapai kebenaran dapat ditumbuhkembangkan melalui pengajaran sejarah secara efektif.

Salah satu alternatif pemecahan masalah di atas adalah dengan mengubah suasana pembelajaran yang berpusat pada guru menjadi pembelajaran yang berpusat pada siswa yaitu menggunakan teknik pembelajaran yang tepat. Dalam mengatasi masalah ini peneliti mencoba menerapkan teknik brainstorming, yang sering disebut curah pendapat atau sumbang saran. Teknik brainstorming akan melibatkan siswa secara langsung dan mengalami sendiri proses belajar dan setiap siswa dapat mencurahkan gagasan-gagasan yang mereka miliki tanpa ada tekanan.

Model brainstorming memiliki syarat yaitu gagasan dari seseorang tidak dapat ditanggapi dan dikritik oleh peserta lain maupun guru. Dengan adanya syarat tersebut tentunya memberikan keberanian bagi siswa yang takut berbicara di depan kelas menjadi lebih berani dan lebih aktif dalam pembelajaran. Diharapkan dengan teknik brainstorming dapat membantu meningkatkan kreativitas siswa dalam belajar.

Jenis penelitian dalam penelitian ini adalah quasi experiment (eksperimen semu) dengan tujuan untuk mengetahui ada tidaknya akibat dari suatu perlakuan yang ditujukan pada subjek yaitu siswa. Penelitian ini dimaksudkan untuk mengetahui ada atau tidaknya pengaruh model brainstorming terhadap kreativitas siswa. Penelitian ini melibatkan dua kelas yaitu kelas eksperimen dan kelas kontrol. Kedua kelas ini mendapatkan perlakuan yang berbeda. Kelas eksperimen menggunakan model brainstorming sedangkan kelas kontrol menggunakan model ceramah yang monoton. 


\section{PEMBAHASAN}

Adapun data hasil pembahasan yang dideskripsikan dalam penelitian ini adalah hasil post test kelas eksperimen dan kelas kontrol yang kemudian akan dilakukan uji prasyarat yakni dengan uji normalitas data dan uji homogenitas data.

\section{A. Data Skor Posttest Kelas Eksperimen}

Berdasarkan hasil post test yang diberikan di kelas eksperimen yaitu kelas X TSM 1 ada 23 orang siswa pada kelas eksperimen yang masuk dalam kriteria kreatif karena skor hasil angket mereka $\geq 75$, dan ada 7 orang siswa yang tidak kreatif dengan skor hasil angket $<75$. Dan secara keseluruhan, siswa pada kelas eksperimen dikatakan kreatif.

Tabel Distribusi Frekuensi Kelas Eksperimen

\begin{tabular}{|c|c|c|c|c|c|}
\hline No. & Nilai & $\mathrm{F}$ & $\mathrm{Fk}$ & $\mathrm{T}_{\mathrm{b}}$ & $\mathrm{T}_{\mathrm{a}}$ \\
\hline 1 & $63-65$ & 2 & 2 & 62,5 & 66,5 \\
\hline 2 & $66-68$ & 2 & 4 & 65,5 & 68,5 \\
\hline 3 & $69-71$ & 3 & 7 & 68,5 & 71,5 \\
\hline 4 & $72-74$ & 0 & 7 & 71,5 & 74,5 \\
\hline 5 & $75-77$ & 20 & 27 & 74,5 & 77,5 \\
\hline 6 & $78-80$ & 3 & 30 & 77,5 & 80,5 \\
\hline \multicolumn{7}{|c|}{$\Sigma 30$} & & & & \\
\hline
\end{tabular}

\section{B. Data Skor Posttest Kelas Kontrol}

Berdasarkan hasil post test yang diberikan di kelas kontrol yaitu kelas X TSM 2 ada 7 orang siswa pada kelas kontrol yang masuk dalam kriteria kreatif karena skor hasil angket mereka $\geq 75$, dan ada 23 orang siswa yang tidak kreatif dengan skor hasil angket $<75$. Dan secara keseluruhan, siswa pada kelas kontrol dikatakan tidak kreatif. 
Tabel Distribusi Frekuensi Kelas Kontrol

\begin{tabular}{|c|c|c|c|c|c|}
\hline No. & Nilai & $\mathrm{F}$ & $\mathrm{Fk}$ & $\mathrm{T}_{\mathrm{b}}$ & $\mathrm{T}_{\mathrm{a}}$ \\
\hline 1 & $63-65$ & 2 & 2 & 62,5 & 66,5 \\
\hline 2 & $66-68$ & 2 & 4 & 65,5 & 68,5 \\
\hline 3 & $69-71$ & 3 & 7 & 68,5 & 71,5 \\
\hline 4 & $72-74$ & 0 & 7 & 71,5 & 74,5 \\
\hline 5 & $75-77$ & 20 & 27 & 74,5 & 77,5 \\
\hline 6 & $78-80$ & 3 & 30 & 77,5 & 80,5 \\
\hline & & & & & \\
\hline
\end{tabular}

Berdasarkan data skor hasil post test pada kelas eksperimen dan kelas kontrol, maka diperoleh nilai rata-rata, standart deviasi dan varians sebagai berikut:

Tabel Nilai rata-rata, standart deviasi, dan varians

\begin{tabular}{|c|c|c|}
\hline Keterangan & Kelas eksperimen & Kelas kontrol \\
\hline Rata-rata (Mean) & 74,06 & 69,43 \\
\hline Standart Deviasi & 3,97 & 4,576 \\
\hline Varians & 15,76 & 20,93 \\
\hline
\end{tabular}

\section{A. Pengujian Persyaratan Analisis}

Setelah dilakukan posttest di kelas eksperimen dan kelas kontrol, maka dilakukan pengujian prasyarat analisis yaitu uji kesamaanya dengan menggunakan uji t dengan syarat data harus normal dan homogen. Berikut akan dijelaskan mengenai uji normalitas dan uji homogenitas di kedua sampel yaitu kelas eksperimen dan kelas kontrol. 


\section{a. Uji Normalitas}

Pengujian dilakukan menggunakan uji Liliefors (L) dengan tujuan untuk mengetahui apakah data yang digunakan berdistribusi normal atau tidak. Setelah dilakukan perhitungan, diperoleh hasil data sebagai berikut:

Uji normalitas data post test kreatif siswa di kelas eksperimen diperoleh $\mathrm{L}_{0}=$ 0,161 . Dengan $\alpha=0,05$ dan $n=30$, maka diperoleh nilai kritis untuk uji Liliefors harga $\mathrm{L}_{\text {tabel }}=0,161 . \mathrm{L}_{0}(0,161)<\mathrm{L}_{\text {tabel }}(0,161)$, ini berarti data berdistribusi normal. Uji normalitas data post test kreatif siswa di kelas kontrol diperoleh $\mathrm{L}_{0}=0,0883$. Dengan $\alpha=0,05$ dan $\mathrm{n}=30$, maka diperoleh nilai kritis untuk uji Liliefors harga $\mathrm{L}_{\text {tabel }}=0,161 . \mathrm{L}_{0}(0,0883)<\mathrm{L}_{\text {tabel }}(0,161)$, ini berarti data berdistribusi normal. Hasil uji normalitas dapat dilihat pada tabel berikut ini:

Tabel Hasil Uji Normalitas

\begin{tabular}{|c|c|c|}
\hline Statistik & $\begin{array}{c}\text { Post test } \\
\text { kelas eksperimen }\end{array}$ & $\begin{array}{c}\text { Post test } \\
\text { kelas kontrol }\end{array}$ \\
\hline $\mathrm{N}$ & 30 & 30 \\
\hline Mean & 74,06 & 69,43 \\
\hline $\begin{array}{c}\text { Standart } \\
\text { Deviasi }\end{array}$ & 3,97 & 4,576 \\
\hline Lhitung $^{\text {Ltabel }}$ & 0,161 & 0,0883 \\
\hline Kesimpulan & $\begin{array}{c}\text { Berdistribusi } \\
\text { normal }\end{array}$ & $\begin{array}{c}\text { Berdistribusi } \\
\text { Normal }\end{array}$ \\
\hline
\end{tabular}

\section{b. Uji Homogenitas}

Uji homogenitas bertujuan untuk mengetahui apakah data mempunyai varians yang homogen atau tidak. Hasil perhitungan uji homogenitas data dengan menggunakan uji $F$. Jika $F_{\text {hitung }} \geq F_{\text {tabel }}$ maka kedua varians berbeda atau tidak homogen. Sedangkan jika $F_{\text {hitung }}<F_{\text {tabel }}$ maka kedua varians sama atau homogen. Dengan taraf nyata $\alpha=0,05$. Secara ringkas, hasil uji homogenitas disajikan pada tabel berikut : 
Tabel Hasil Uji Homogenitas

\begin{tabular}{|c|c|c|c|c|}
\hline Kelas & & & & Kesimpulan \\
& Varians & Fhitung & Ftabel & \\
\hline Kontrol & 20,93 & & 1,84 & Homogen \\
& & 1,328 & & \\
\hline Eksperimen & 15,76 & & 1,84 & Homogen \\
& & 1,328 & & \\
\hline
\end{tabular}

Dari tabel diatas dapat dilihat bahwa nilai varians kelas kontrol adalah 20,93 dan kelas kelas eksperimen 15,76. Nilai $F_{\text {hitung }}$ adalah 1,328 dan $F_{\text {tabel }} 1,84$. Hasil perhitungan menunjukkan bahwa $F_{\text {hitung }}(1,328)<\mathrm{F}_{\text {tabel }}(1,84)$ artinya data bersifat homogen.

\section{c. Uji Hipotesis}

Setelah dilakukan uji normalitas diketahui bahwa sampel kedua kelas berdistribusi normal dan memiliki varians yang homogen maka dilakukan pengujian hipotesis menggunakan uji $\mathrm{t}$ bebas. Uji $\mathrm{t}$ bebas digunakan untuk mengetahui apakah metode brainstorming mempengaruhi kreativitas siswa.

Setelah diberikan perlakuan maka diperoleh nilai rata-rata kelas eksperimen 74,06 dan nilai rata-rata kelas kontrol 69,43. Secara ringkas, perhitungan uji hipotesis kelas eksperimen dan kelas kontrol dapat dilihat pada tabel berikut:

Tabel Hasil Uji Hipotesis

\begin{tabular}{|c|c|l|l|l|}
\hline Kelas & $\begin{array}{l}\text { Skor } \\
\text { Rata- } \\
\text { Rata }\end{array}$ & $t_{\text {thing }}$ & $\mathrm{t}_{\text {tabel }}$ & \multicolumn{1}{|c|}{ Kesimpulan } \\
\hline Kontrol & 69,43 & 4,4179 & 2,00172 & $\begin{array}{l}\text { Ada pengaruh } \\
\text { model } \\
\text { brainstorming pada } \\
\text { pelajaran sejarah } \\
\text { terhadap kreativitas } \\
\text { siswa }\end{array}$ \\
\hline Eksperimen & 74,06 & & \\
\hline
\end{tabular}

Dari tabel diatas dapat dilihat bahwa skor rata-rata kelas kontrol adalah 69,43

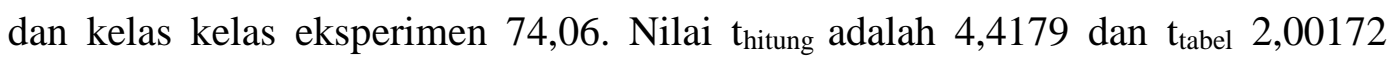
dengan derajat kebebasan $\mathrm{df}=\mathrm{n}-\mathrm{k}$. Hasil perhitungan menunjukkan bahwa $\mathrm{t}_{\mathrm{itung}}$ 
$(4,4179)>\mathrm{t}_{\text {tabel }}(2,00172)$ yang berarti bahwa ada pengaruh model brainstorming pada pelajaran sejarah terhadap kreativitas siswa.

\section{Pembahasan}

Kreativitas siswa dalam belajar dipengaruhi oleh cara mengajar guru atau model pembelajaran yang digunakan oleh guru. semakin sesuai model yang digunakan semakin baik pula hasilnya. Penelitian ini menggunakan dua model pembelajaran yang berbeda yaitu model brainstorming dan model ceramah. Kedua sampel diajarkan dengan model yang berbeda, kelas eksperimen (X TSM 1) diajarkan menggunakan model brainstorming dan kelas kontrol (X TSM 2) diajarkan menggunakan model ceramah.

Pada akhir pertemuan siswa diberikan posttest berupa angket kreativitas siswa untuk mengetahui bagaimana kemampuan kreativitas siswa pada kedua kelas setelah diberikan perlakuan yang berbeda. Berdasarkan hasil penelitian menunjukkan bahwa ada pengaruh model brainstorming pada pelajaran sejarah terhadap kreativitas siswa. Hal ini dapat dilihat dari skor rata-rata siswa kelas eksperimen (kelas yang diberi perlakuan dengan menggunakan model brainstorming) yaitu 74,06 dan skor rata-rata siswa kelas kontrol yang menggunakan metode ceramah adalah 69,43.

Berdasarkan skor rata-rata kedua kelas diatas, nilai posttest kelas kontrol berbeda dengan nilai posttest kelas eksperimen. Pada kelas eksperimen yang menggunakan model brainstorming lebih banyak siswa yang mendapatkan skor tinggi ( $\geq 75)$ dibandingkan siswa pada kelas kontrol yang menggunakan metode ceramah yang lebih banyak mendapatkan skor $(\leq 75)$. Untuk melihat perbedaan skor hasil posttest siswa pada kelas eksperimen dan kelas kontrol maka dilakukan uji persyaratan yaitu uji normalitas dan uji homogenitas. Dari hasil perhitungan uji normalitas menunjukkan data kedua kelas bersifat normal, dan kedua kelas bersifat homogen.

Selanjutnya dilakukan uji hipotesis yaitu dengan melakukan uji t bebas untuk melihat adakah pengaruh model brainstorming terhadap kreativitas siswa di kelas yang diberi perlakuan dan tidak diberi perlakuan. Dari tabel 4.4 perhitungan 
menunjukkan bahwa $t_{\text {hitung }}(4,4179)>t_{\text {tabel }}(2,00172)$ yang berarti bahwa ada pengaruh model brainstorming pada pelajaran sejarah terhadap kreativitas siswa. Ini berarti ada perbedaan antara kreativitas siswa yang belajar menggunakan model brainstorming dengan siswa yang belajar menggunakan model ceramah.

Pada saat diterapkannya model brainstorming di kelas eksperimen yaitu kelas X TSM 1 ada beberapa perbedaan dibandingkan dengan kelas kontrol X TSM 2 yang menggunakan model ceramah. Ketika diterapkan model brainstorming di kelas eksperimen hampir seluruh siswa antusias dan ingin ikut berperan aktif dalam kegiatan diskusi kelompok, mereka berlomba mencari jawaban untuk menjawab dan memecahkan masalah yang diberikan.

Siswa yang biasanya sering diam dan tidak aktif dalam kegiatan diskusi kelompok juga mulai berani menyampaikan pendapat dan jawaban. Penerapan model brainstorming yang tidak membatasi siswa untuk menyampaikan pendapatnya membuat siswa berani tampil dalam kegiatan diskusi. Saat persentase kelompok berlangsung juga terjadi perdebatan pendapat antara kelompok. Mereka berusaha tetap mempertahankan jawaban mereka sehingga mereka terus mencari jawaban dari berbagai sumber seperti internet dan buku. Manfaat lain yang terjadi karena penerapan metode brainstorming adalah tidak ada lagi siswa yang mengantuk saat pembelajaran berlangsung dan siswa menjadi lebih rajin membaca untuk mempertahankan jawaban mereka.

Ketika diterapkannya model brainstorming tanpa disadari mereka telah menggali kreativitas mereka dalam belajar yang selama ini tidak begitu terlihat. Selanjutnya ketika menjawab posttest ada perbedaan jawaban yang signifikan antara kelas eksperimen dan kelas kontrol. Hal ini dapat dilihat dari skor rata-rata kedua kelas tersebut dimana pada kelas eksperimen yang menggunakan model brainstorming lebih banyak siswa yang mendapatkan skor tinggi ( $\geq 75)$ dan dikategorikan kreatif dibandingkan siswa pada kelas kontrol yang menggunakan metode ceramah yang lebih banyak mendapatkan skor $(\leq 75)$.

Penerapan model ceramah di kelas kontrol. Ketika menerapkan model ini peran guru sangat penting karena jika guru kurang tepat dalam menerapkan model ini maka siswa akan merasa bosan dan mengantuk, tetapi sebaliknya jika guru 
cerdas menggunakan model ini maka siswa juga bisa tertarik dalam kegiatan pembelajaran.

Ketika model ceramah ini diterapkan di kelas kontrol, tidak semua siswa aktif dalam pembelajaran, hanya beberapa siswa yang memang aktif saja yang berantusias dan semangat dalam belajar. Sedangkan sebagian siswa lain hanya mendengarkan dan tidak aktif saat belajar. Saat dilakukan kegiatan diskusi dan guru memberikan pertanyaan, hanya beberapa siswa saja yang berusaha mencari jawaban dari buku dan internet dan siswa yg lainnya hanya membaca buku saja tetapi tidak berani menyampaikan jawabannya, bahkan ada beberapa siswa yang hanya diam saja.

Sedangkan saat kegiatan diskusi kelompok di kelas eksperimen yang diajarkan dengan model brainstorming, siswa aktif dan sangat antusias mencari jawaban dari berbagai sumber seperti buku dan internet untuk menjawab dan memecahkan masalah yang diberikan oleh guru. Siswa juga tidak terlihat bosan dan mengantuk.

\section{III.PENUTUP}

Siswa yang diajarkan menggunakan model brainstorming lebih antusias dan ingin ikut berperan aktif dalam kegiatan diskusi kelompok, mereka berlomba mencari jawaban untuk menjawab dan memecahkan masalah yang diberikan. Siswa yang biasanya sering diam dan tidak aktif dalam kegiatan diskusi kelompok juga mulai berani menyampaikan pendapat dan jawaban.

Hal ini berarti model brainstorming mempengaruhi kreativitas siswa dalam mencari jawaban dari pertanyaan yang diberikan oleh guru. Hal ini dibuktikan dari hasil perhitungan secara statistik dimana $t_{\text {hitung }}(4,4179)>t_{\text {tabel }}(2,00172)$ yang berarti bahwa ada pengaruh model brainstorming pada pembelajaran sejarah. 


\section{DAFTAR REFERENSI}

Arikunto, Suharsimi. 1996. Manajemen Penelitian. Jakarta: Rineka Cipta

Daliman. 2012. Model Penelitian Sejarah. Yogyakarta: Ombak

Dewi, Rosmala. (2010). Perkembangan Kognitif Anak Usia Prasekolah. Medan:

Unimed Pascamuda.

Hariyono. 1995. Mempelajari Sejarah Secar Efektif. Malang: Pustaka Jaya

Hamalik, Oemar. 2013. Kurikulum dan Pembelajaran. Jakarta : Bumi Aksara.

Munandar, Utami. 1999. Mengembangkan Bakat dan Kreativitas Anak Sekolah. Jakarta: PT Gramedia

Munandar, Utami. 2012. Pengembangan Krreativitas Anak Berbakat. Jakarta: Rineka Cipta

Ngalimun. 2016. Strategi Dan Model Pembelajaran. Yogyakarta: Aswaja Pressindo.

Rachmawati, Yeni. dkk. 2016. Strategi Pengembangan Kreativitas Anak.Jakarta: Kencana

Roestiyah. 2012. Strategi Belajar Mengajar. Jakarta: Rineka Cipta

Sani, Ridwan Abdul. 2015. Inovasi Pembelajaran. Jakarta: Bumi Aksara

Sjamsuddin, Helius. 2012. Metodologi Sejarah. Yogyakarta: Ombak

Sudijono, Anas. 2015. Pengantar Statistika Pendidikan. Jakarta: PT Raja Grafindo Persada

Sukmadinata, Nana Syaodih. 2011. Model Penelitian Pendidikan: Rosda

Sugiyono. 2015. Model Penelitian Pendidikan: Pendekatan Kuantitatif, Kualitatif dan R\&D. Bandung: Alfabeta

Sugiyono. 2016. Statistika Untuk Penelitian. Bandung: Alfabeta

Yulianti, Tri Rosana. 2004. Peranan Orang Tua Dalam Mengembangkan

Kreativitas Anak Usia Dini. Jurnal Empowerment. 13:2252-4738 